\title{
FLOOD VULNERABILITY ASSESSMENT BY FLOOD VULNERABILITY INDEX (FVI) METHOD: A STUDY ON SIRAJGANJ SADAR UPAZILA
}

\author{
Mst. Airen Aktar ${ }^{\mathrm{a}}$, Kanij Shohani ${ }^{\mathrm{b}}$, Md. Nazmul Hasan ${ }^{\mathrm{c}}$ and Md. Kamrul Hasan ${ }^{\mathrm{d} \star}$ \\ aDepartment of Urban and Regional Planning, Pabna University of \\ Science \& Technology, Pabna, Bangladesh; e-mail: mst.airenaktaraakhi@gmail.com \\ ${ }^{b}$ Department of Urban and Regional Planning, Pabna University of \\ Science \& Technology, Pabna, Bangladesh; e-mail: kanijshohani@gmail.com \\ ${ }^{b}$ Department of Urban and Regional Planning, Pabna University of \\ Science \& Technology, Pabna, Bangladesh; e-mail: hasanmdnazmul052@gmail.com \\ dAssistant Professor, Department of Urban and Regional Planning, Pabna University \\ of Science \& Technology, Pabna, Bangladesh. e-mail: kamrul.urp@pust.ac.bd \\ ${ }^{*}$ Correspondence: Assistant Professor, Department of Urban and Regional Planning, \\ Pabna University of Science \& Technology, Pabna-6600, Bangladesh. \\ E-mail: kamrul.urp@pust.ac.bd; Tel.: +880-1783571409
}

\begin{abstract}
Flood is one of the most common and extreme hazards in Bangladesh because of its geographical location. Sirajganj is a district with the highest flood propensity in Bangladesh. The study aims to evaluate the vulnerability in the ten Unions of Sirajganj Sadar upazila to the flood hazard. Different forms of vulnerability evaluation approaches differ in their method. The Flood Vulnerability Index (FVI) method has been implemented in this research to determine flood vulnerability in order to classify which areas of the study are the most vulnerable to flooding. For the study of flood vulnerability, three indicators (i.e. exposure, sensitivity and resilience, etc) are selected in four dimensions (social, financial, environmental and physical). The FVI calculation determines the flood vulnerability index scores for each union. Following the analysis of FVI, in Sirajganj Sadar Upazila Mechhra union is marked as being highly vulnerable. Since this union is very poor in adaptability, coping capacity and resilience; exposure and susceptibility are greater. The other syndicates are highly exposed to floods. Finally, the zoning map for flood risk was developed on the basis of vulnerability index ratings.
\end{abstract}

Keywords: Vulnerability; Flood Vulnerability Index; Exposure; Susceptibility; Resilience 


\section{Introduction}

Bangladesh is one of the world's biggest rivers with a dense network of Ganges, Brahmaputra with Meghna distributors, and over 230 main rivers and tributaries. The basin Ganges, Brahmaputra and Meghna occupies a net total area of roughly $1.76 \times 106$ square kilometers spanning Bangladesh, Bhutan, China, India and Nepal. Just 7\% of this vast catchment area is in Bangladesh. The country's monthly yearly precipitation ranges from 1500 to $5000 \mathrm{~mm}$ with an average of $2300 \mathrm{~mm}$. Bangladesh is particularly vulnerable to flood dangers due to its geographical location, land characteristics, the multitude of rivers and the mountain climate. The floods are annual, with the worst floods happening in July and August. A few days now, the earth has been flooded, inhabitants have been displaced on a wide scale and economic disruption and ecological impacts have been immense. Global warming such as climate change, demographic and economic development and urbanization is exacerbating floods. As a consequence, floods routinely affect life and livelihoods (Bhattacharya et al, 2013).

In Bangladesh, flooding is by far the most frequent and dangerous threat. During the monsoon season, the volume of water flowing into Bangladesh from upstream exceeds the rivers' capacity. Each year, over $26,000 \mathrm{~km}^{2}$ (roughly 18 percent of the country) of Bangladesh is flooded, killing over 5,000 people and damaging over seven million homes due to melt water from the Himalayas. Floods have wreaked havoc on Bangladesh throughout its history, especially in 1966, 1987, 1988, and 1998. (Disaster Management in Bangladesh, 2003).

Sirajganj is one of Bangladesh's worst-affected districts due to flooding. Since so much of Sirajganj district is located along the Jamuna River, it is regularly flooded and eroded. Because of the comparatively low lying areas and deltas, as well as the presence of a large river called Brahmaputra, the ten unions of this Upazila are the most vulnerable to flooding (Bhuyian, 2014). In this report, the Flood Vulnerability Index (FVI) approach is used to assess flood hazard vulnerability in order to determine which areas in Sirajganj Sadar Upazila are the most vulnerable to flooding (FVI).

\section{Literature review}

In contrast to other methods, the indicator-based approach offers a more detailed image of overall flood vulnerability in each region. In flood risk management, vulnerability is the most important factor to consider. One of the most important goals of flood vulnerability assessment is to establish a direct link between theoretical flood vulnerability conceptions and the day-to-day administrative process. Since a variety of methods to assessing vulnerability have been adopted, authorities must choose the most suitable technique. Curve method, catastrophe loos data method, computer simulation methods, and indicator based methods are the four most commonly used evaluation methods (Nasiri et al., 2016).

The report, titled "Flood vulnerability index as a knowledge base for flood risk assessment in urban areas," focused on the flood vulnerability index as a knowledge base for flood risk assessment in urban areas. There is a need to develop flood risk management strategies due to the magnitude of the effects of flooding. The assessment of flood risk at the urban scale is one of the most critical aspects of flood management. Many studies have been conducted on flood danger, including flood vulnerability assessments, because understanding vulnerability is important not only for the survival of communities that are vulnerable to extreme flooding, but also for their adaptation to climate change. Developing a Flood Vulnerability Index is one strategy for achieving this aim (FVI). The Vulnerability Index will assess which areas are the most vulnerable to flooding and should be taken into account during potential 
redevelopments. That is, FVI establishes a connection between theoretical flood vulnerability expectations and the day-to-day flood management process. This research is largely focused on the flood risk literature (Nasiri, 2013).

The study "Community Vulnerability Assessment Tool Methodology" developed the Community Vulnerability Assessment Tool (CVAT), a danger and vulnerability assessment methodology that aids emergency managers and planners in their efforts to minimize hazard vulnerabilities through hazard mitigation, systematic landuse, and development planning. The model takes into account a variety of threats, such as storm surge, wind, and tornadoes, and provides a methodology for identifying and prioritizing them. The model also defines sensitive facilities (e.g., police, fire, hospitals, shelters, services, and so on) and calculates their vulnerability to physical and operational hazards. A small number of inputs are used in a social vulnerability study, but the analysis is not exhaustive (Flax et al., 2002).

This paper, titled "Reducing the Complexity of the Flood Vulnerability Index," examines the findings of an examination conducted to select the most important indicators in order to create a frugal use of the FVI. This approach is applicable at three different spatial scales (river basin, sub-catchment, and urban) and to the various components of flood vulnerability (social, economic, environmental, and physical), just as it was with the original methodology. Improvements to the FVI methodology were made by assessing the indicators' importance and studying the key indicators needed to effectively represent the reality of the fluvial floods. This was accomplished by the use of statistical methods (a derivative and a correlation method) as well as expert expertise (via a questionnaire). Finally, both of these approaches were combined to define the most important indicators and simplify the FVI equations. After its complexity is reduced, the FVI can be more easily used as a tool for flood risk reduction, decision-making enhancement, and education (Balica \& Wright, 2010).

The article "Social Impacts and Flood Vulnerability in Bangladesh and Nepal" looked at flood vulnerability, impacts, and coping strategies in Bangladesh and Nepal, with the goal of proposing a long-term mitigation strategy. According to historical data, floods in Bangladesh and Nepal have increased in frequency, severity, and length since 1970, causing significant human suffering, disruptions in normal life and activity, infrastructure, crop and agricultural destruction, and severe economic impacts. Both countries' disaster management bureaus have already organized numerous trainings, conferences, and seminars to disseminate scientific information and disaster preparedness practices to disaster managers and increase public awareness. Apart from modern flood control methods, the people of these countries have lived with flooding for centuries, depending on traditional/indigenous knowledge and other local adaptation practices. It is critical that indigenous, traditional, and conventional traditions be incorporated into national and regional policy, and this should be accomplished through a participatory process involving policymakers and relevant stakeholders (Dewan, 2015).

The article "Community Responses to Flood Early Warning System: Case Study in Kaijuri Union, Bangladesh" examined community-based flood early warning system responses. Early alert is a vital aspect of reducing disaster risk. There have been significant advances in medium-range and seasonal forecasting in recent decades. This paper outlines an integrated framework for medium-range flood forecasting that is focused on the needs of agricultural users in order to minimize flood impacts on the farming community. Danger and vulnerability evaluations were carried out by group consultation as part of the methodology. Based on farmers' needs for early warning, the study included creating a flood risk map and response options to flood risk probabilistic forecasts. The ability to use probabilistic forecasts for organizational decision-making is demonstrated in this report. Focus group meetings, informal interviews, and surveys were used to determine the predicted lead-time requirements, 
impacts, and management options for crops and livestock. The findings included flood risk mapping focused on the study area's communities' exposure to flooding, as well as early warning impacts before and after flood events (Fakhruddin et al., 2015).

The research "Flood hazards and vulnerability assessment in a Riverine Flood Prone Region: a case study" aims in a remote sensing and geographic information system to evaluate the danger and vulnerabilities of riverine floods in a flood-prone area (GIS). Flood frequency analyzes are carried out for the purpose of assessing flood risk and vulnerability to various levels. The vulnerability feature is developed for settlement and fisheries vulnerability maps. Depth harm relationship has been established for the development of the vulnerability feature. In order to generate a Raster-based vulnerability chart, vulnerability functions of settlement and fishing are utilized. The flux frequency analysis demonstrates the best fitting distribution for flood frequency analysis in the study area of Pearson form III distribution. In the 100-year return cycle, floods represent 48, 35, 53 and 38 respectively, respectively, for the total agricultural, settlement, and fishery areas. Vulnerability has been observed in settlement areas that are scaled down to low, very low, moderate, high and very high. The vulnerable fishery areas of 18,19, 9, 3 and 4 percent in 100 years of water supply are poor, extremely low, moderate, high and very high. The research findings may be useful for a potential flood mitigation strategy in the field of study (Bhuiyan, 2014).

\section{Research materials and methods}

\subsection{Study Area Profile}

Sirajganj Sadar Upazila (Sirajganj district) area 320.15 sq. km, located in between $24^{\circ} 22^{\prime}$ and $24^{\circ} 37^{\prime}$ north latitudes and in between $89^{\circ} 36^{\prime}$ and $89^{\circ} 47^{\prime}$ east longitudes. The study area is unions of Sirajganj Sadar Upazila which is one of the worst flood affected region of Bangladesh. It was surrounded by a network of rivers namely Jamuna. Sirajganj Sadar Upazila located at the right side of Jamuna River. Every year this Upazila flooded in monsoon rainfall period from July to September. All union of this Upazila are vulnerable to flood. Flood vulnerability analysis is important for understanding which unions are more vulnerable and which unions are less vulnerable to flood. Every year flood occurs in this Upazila and is very vulnerable to flood because of its geographic location and Jamuna River. That's why Sirajganj Sadar Upazila is selected as the study area. 


\section{SIRAJGANJ SADAR UPAZILA}

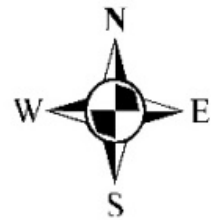

\section{Legend}

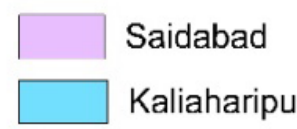

Shialkul

Sirajganj Sadar

Bahuli

Khoksabari

Koakhola

Baghbati

Chhangachha

Mechhra

Ratankandi
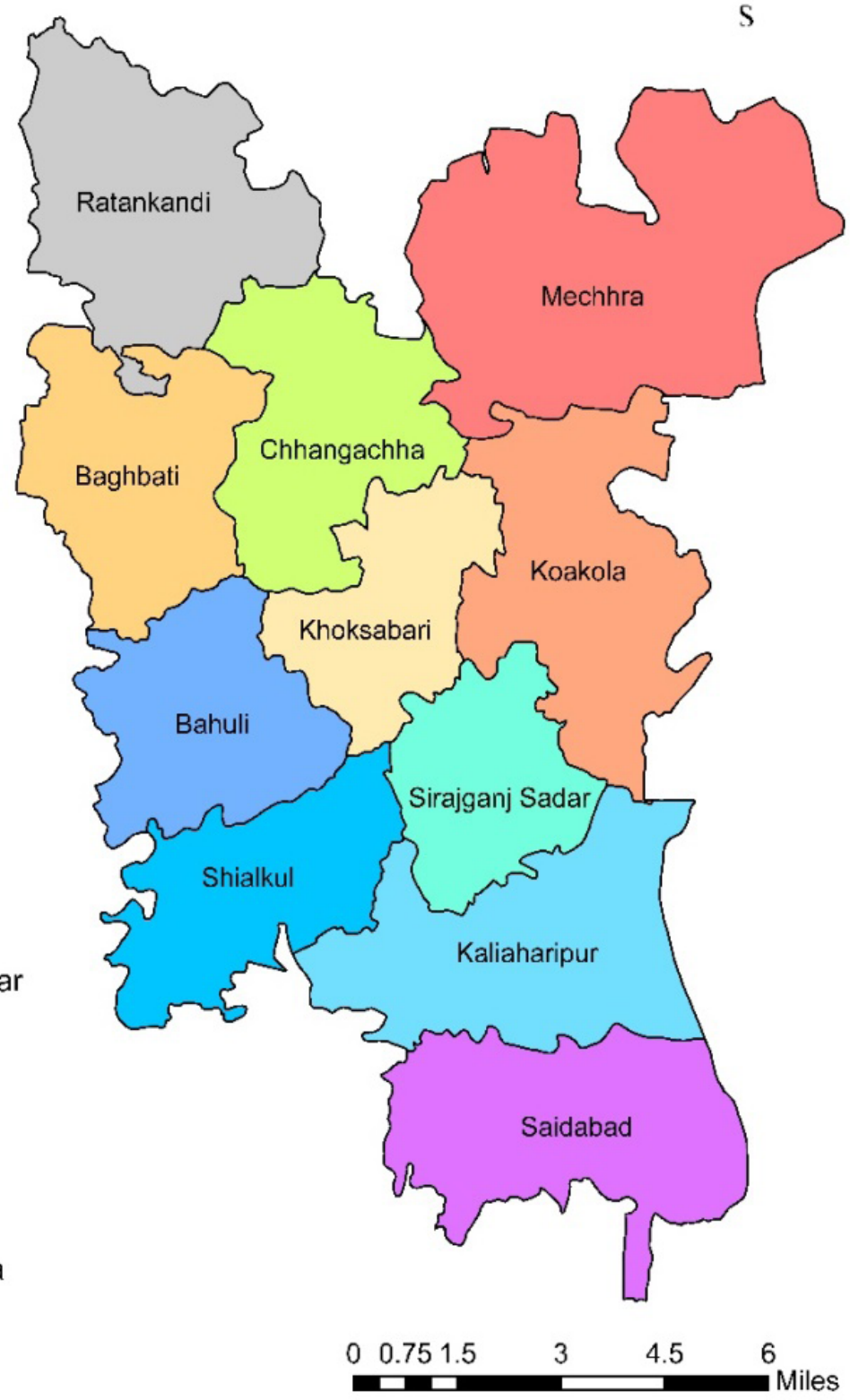

(Source: Author, 2019)

Figure 1. Study Area (Sirajganj Sadar Upazila)

Sirajganj Sadar Upazila consists of ten unions namely Baghbati, Bahuli, Kalia Haripur, Kaoakola, Khoksabari, Mechhra, Ratankandi, Saidabad, Shialkul, Chhangachha. Basic Information about these ten unions is shown in table1. 
Table 1. Union Wise Distribution in Sirajganj Sadar Upazila

\begin{tabular}{|l|c|c|c|c|c|c|}
\hline Union Name & Population & $\begin{array}{c}\text { Population } \\
\text { Density }\end{array}$ & $\begin{array}{c}\text { Population } \\
\text { Growth } \\
\text { Rate (\%) }\end{array}$ & $\begin{array}{c}\text { Literacy } \\
\text { Rate (\%) }\end{array}$ & $\begin{array}{c}\text { Child mor- } \\
\text { tality Rate }\end{array}$ & $\begin{array}{c}\text { Disable } \\
\text { People }\end{array}$ \\
\hline Baghbati & 53015 & 1994 & 1.77 & 41.9 & 4.6 & 1.4 \\
\hline Bahuli & 39403 & 1661 & 1.14 & 39.1 & 4.6 & 1.2 \\
\hline Kalia Haripur & 50400 & 1786 & 1.37 & 44.0 & 4.6 & 2.5 \\
\hline Kaoakola & 17713 & 541 & 1.35 & 31.1 & 4.6 & 1.0 \\
\hline Khoksabari & 302705 & 1549 & 0.69 & 44.8 & 4.6 & 2.1 \\
\hline Mechhra & 24766 & 486 & 1.59 & 35.4 & 4.6 & 1.8 \\
\hline Ratankandi & 48916 & 1467 & 0.33 & 40.7 & 4.6 & 1.5 \\
\hline Saidabad & 47610 & 1328 & 2.08 & 40.7 & 4.6 & 4.6 \\
\hline Shialkul & 45965 & 1882 & 1.88 & 45.1 & 4.6 & 1.1 \\
\hline Chhangachha & 381709 & 1406 & 1.09 & 43.9 & 4.6 & 1.9 \\
\hline
\end{tabular}

(Source: Field survey, 2019)

\subsection{Flood Vulnerability Index (FVI)}

Because of the increased flood hazard, better approaches must be established to help decision-making in flood risk management. The Flood Vulnerability Index (FVI) is a tool focused on indicators. The FVI has been thoroughly evaluated with regard to all components of a flood disaster that are most likely to be affected: social, economic, environmental and physical. The FVI tests the vulnerability level for each factor (exposure, susceptibility and resilience). Vulnerability itself is known to be a combination of exposure, susceptibility and resilience:

Vulnerability $=($ Exposure $\times$ Susceptibility) $/$ Resilience (Balica and Wright, 2010).

This study's evolved approach aims to assess flood vulnerability in three ways: (1) visibility, (2) susceptibility, and (3) resilience. These variables are defined as follows by (Pouya et al., 2017): People, property, structures, and other elements that are present in hazard zones and are thus exposed to potential losses have been described as exposure. Flooding can have an effect on humans and physical objects, which is known as exposure. The values that are present at the place where floods occur can be understood. Exposure is a term that is used to describe the process Goods, facilities, cultural heritage, agricultural lands, and people can all be included among these values. The elements revealed within the framework that affect the probabilities of being harmed in a flooding situation are referred to as susceptibility. General population, social ties, and institutional growth data are among the susceptibility measures. The ability of a system, population, or society exposed to hazards to withstand, absorb, and recover from the effects of a hazard is known as resilience. Political, administrative, environmental, and social organizational evaluations are all used to assess resilience. 
Flood vulnerability is an important factor to consider when assessing flood risk and assessing damage. Many methods for assessing flood susceptibility have been developed by researchers. It's difficult to quantify flood vulnerability because it depends on a variety of factors including social, economic, environmental, physical, and even political factors. The selection of indicators is the first step in any indicator-based vulnerability assessment. There are three types of vulnerability assessment methods: vulnerability index systems, vulnerability curve methods, and disaster loss data (Nasiri, 2013). The vulnerability index system has been used to assess flood vulnerability in Sirajganj Sadar Upazila among these methods. Since this Upazila is heavily populated, it is prone to flooding. Exposure, susceptibility, and resilience are three factors having impacts on calculation of vulnerability. The FVI has been evaluated holistically, taking into account all dimensions that are most likely to be impacted by a flood disaster in Sirajganj Sadar Upazila: social, economic, environmental, and physical. The FVI framework used in this study evaluates the degree of vulnerability for each indicator (exposure, susceptibility, and resilience) across four dimensions and multiple spatial scales.

Table 2 illustrates the appropriate indicators under four factors but it is an important matter that selection of vulnerability indicators is directly relevant to that study context.

Table 2. FVI system components

\begin{tabular}{|c|c|c|c|c|c|c|}
\hline \multirow{2}{*}{ Dimensions } & \multicolumn{6}{|c|}{ Indicators } \\
\hline & Exposure & Acronym & Susceptibility & Acronym & Resilience & Acronym \\
\hline \multirow{6}{*}{ Social } & $\begin{array}{l}\text { Population } \\
\text { Growth }\end{array}$ & $P_{G}$ & \multirow{6}{*}{$\begin{array}{l}\text { Child Mor- } \\
\text { tality }\end{array}$} & \multirow{6}{*}{$C_{M}$} & $\begin{array}{l}\text { Educational status } \\
\text { (Literacy Rate) }\end{array}$ & $E_{S}$ \\
\hline & $\begin{array}{l}\text { Population } \\
\text { Density }\end{array}$ & $P_{D}$ & & & $\begin{array}{c}\text { Awareness \& Pre- } \\
\text { paredness }\end{array}$ & $\mathrm{A} / \mathrm{P}$ \\
\hline & \multirow{4}{*}{ Disable People } & \multirow{4}{*}{$D_{p}$} & & & $\begin{array}{c}\text { Institutional Ar- } \\
\text { rangement }\end{array}$ & $I_{A}$ \\
\hline & & & & & Training Program & $T_{P}$ \\
\hline & & & & & $\begin{array}{c}\text { Indigenous Prac- } \\
\text { tices }\end{array}$ & $I_{P}$ \\
\hline & & & & & Warning System & $W_{S}$ \\
\hline \multirow{3}{*}{ Economic } & $\begin{array}{l}\text { Household } \\
\text { Assets }\end{array}$ & $H_{A}$ & \multirow{3}{*}{$\begin{array}{l}\text { Unemploy- } \\
\text { ment }\end{array}$} & \multirow{3}{*}{$U_{M}$} & $\begin{array}{c}\text { Economic Diversi- } \\
\text { fication }\end{array}$ & $E_{D}$ \\
\hline & $\begin{array}{l}\text { Agricultural } \\
\text { Dependency }\end{array}$ & $A_{D}$ & & & \multirow{2}{*}{ Flood Insurance } & \multirow{2}{*}{$F_{I}$} \\
\hline & $\begin{array}{l}\text { Income } \\
\text { Source }\end{array}$ & $I_{S}$ & & & & \\
\hline \multirow{2}{*}{$\begin{array}{l}\text { Envi- } \\
\text { ron-mental }\end{array}$} & Land Use & $L_{U}$ & \multirow{2}{*}{$\begin{array}{l}\text { River bank } \\
\text { Erosion }\end{array}$} & \multirow[b]{2}{*}{$R_{E}$} & Embankment & $\mathrm{E}$ \\
\hline & $\begin{array}{c}\text { Monsoon } \\
\text { Rainfall }\end{array}$ & $M_{R}$ & & & Water Bodv & $W_{B}$ \\
\hline \multirow{3}{*}{ Physical } & \multirow{2}{*}{$\begin{array}{l}\text { Closeness to } \\
\text { River }\end{array}$} & \multirow[t]{2}{*}{$C_{R}$} & \multirow{3}{*}{$\begin{array}{l}\text { Geographic } \\
\text { Location }\end{array}$} & \multirow{3}{*}{$G_{L}$} & $\begin{array}{c}\text { Communication } \\
\text { System }\end{array}$ & $c_{S}$ \\
\hline & & & & & $\begin{array}{l}\text { Access to Utility \& } \\
\text { Service facility }\end{array}$ & $A_{U S}$ \\
\hline & $\begin{array}{l}\text { Housing Pat- } \\
\text { tern }\end{array}$ & $H_{P}$ & & & Flood Shelter & $F_{S}$ \\
\hline
\end{tabular}

(Prepared by: Author, 2019)

The general formula for FVI is calculated by classifying the component in three groups of indicators: exposure (E), susceptibility $(\mathrm{S})$ and resilience $(\mathrm{R})$ - 
$\mathrm{FVI}=\frac{E * S}{R}$

With regard to indicators this equation is become to following ones (Balica, 2012) -

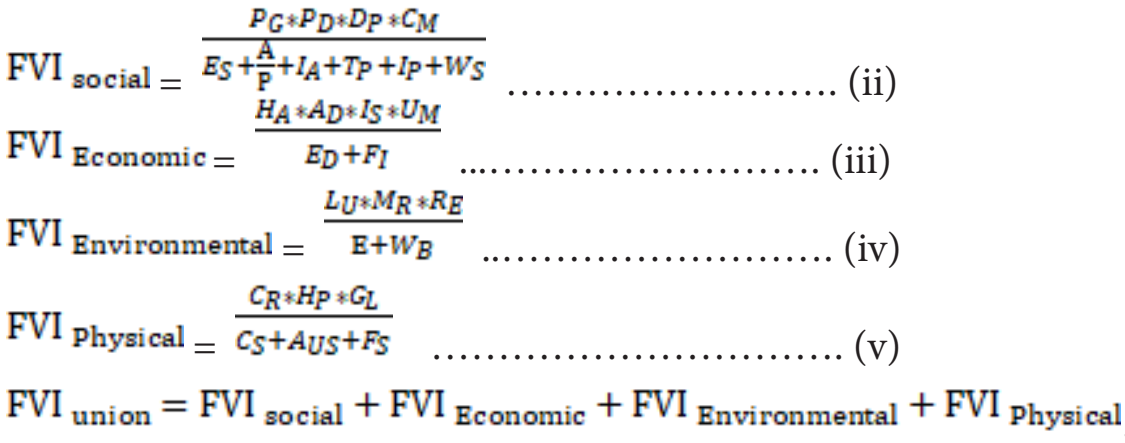

Total FVI of each urban area is the sum of these four indicators based FVI (Eq. ii-vi). This index value indicates extent of vulnerability as follows in below table.

Table 3. Flood vulnerability interpretation (Balica, 2012)

\begin{tabular}{|c|c|}
\hline Index value & Description \\
\hline$<0.01$ & Very small vulnerability to floods \\
\hline $0.01-0.25$ & Small vulnerability to floods \\
\hline $0.25-0.50$ & Vulnerable to floods \\
\hline $0.50-0.75$ & High vulnerability to floods \\
\hline $0.75-1.00$ & Very high vulnerability to floods \\
\hline
\end{tabular}

\section{Flood vulnerability analysis:}

flood vulnerability assessment is analyzed for ten unions (Baghbati, Bahuli, Kalia Haripur, Kaoakola, Khoksabari, Mechhra, Ratankandi, Saidabad, Shialkul, Chhangachha) of Sirajganj Sadar Upazila under Sirajganj district for identifying which unions are more vulnerable and which are low vulnerable to flood by considering social, physical, economic and environmental dimension with such components under three indicators. The current situation and some important data about each indicator of ten unions under Sirajganj Sadar Upazila are observed field field survey, Key Informant Interview (KII), Focus Group Discussion (FGD) and questionnaire survey. A questionnaire has been devised with four main dimensions, concerning the degree of significance of each indicator and the vulnerability components. It has been completed by local people of each union. Some data has been collected from Sirajganj Sadar Upazila office and Bangladesh Water Development Board. The respondents have evaluated the indicator's influence on flood vulnerability in general. Some people are gathered together from similar background to discuss about flood. According to their opinion some classes have been created and weighted each components of each indicators under four dimensions on a scale 5 to 1 , where 5 indicates very high vulnerable and 1 very low vulnerable. Then these weights are normalized. Normalized value is $0.01-1$. Table 4 shows category, weight, and normalized value. The formula of normalization is:

$$
X^{\prime}=\frac{X-\operatorname{Min}}{\operatorname{Max}-\operatorname{Min}} \quad \text { Where, } X^{\prime} \text { is normalized value. }
$$


Table 4. Category and Weight and Normalization Value

\begin{tabular}{|c|c|c|}
\hline Category & Weight & Normalized value \\
\hline Very low vulnerable & 1 & 0 \\
\hline Low vulnerable & 2 & 0.25 \\
\hline Moderate vulnerable & 3 & 0.50 \\
\hline High vulnerable & 4 & 0.75 \\
\hline Very high vulnerable & 5 & 1 \\
\hline
\end{tabular}

(Prepared by: Authors, 2019)

One normalized value has been found for every component. The Flood Vulnerability Index for each dimension (social, economic, environment, physical) is calculated for ten unions using formulas (Eq. ii-v) with these normalized values.

Social vulnerability: The social dimension includes indicators that describe the context, capacity, skills, knowledge, values, beliefs and behavior of individuals, households, organizations and communities at various geographic scales. Social indicators are typically used to assess current conditions or achievements of social goals related to human health, housing, education levels, recreational opportunities and social equity issues (Balica \& Wright, 2010). The indicators for social vulnerability to flood for Sirajganj Sadar Upazila have been chosen as a determinant of vulnerability. For flood vulnerability index, ten components have been chosen, which cover three indicators under social dimension of flood vulnerability and give an overview of the situation. Among ten components, three components indicate exposure, one component indicates susceptibility and six indicate resilience to flood. The components of exposure are Population growth rate ${ }^{\left(P_{G}\right)}$, Population Density $\left(P_{D}\right)$, Disable People ${ }^{\left(D_{P}\right)}$; component of susceptibility is Child Mortality $\left(C_{M}\right)$ and components of resilience are Educational Status (Literacy Rate) $\left(E_{S}\right)$, Awareness \& Preparedness $(A / P)$, Institutional Arrange-

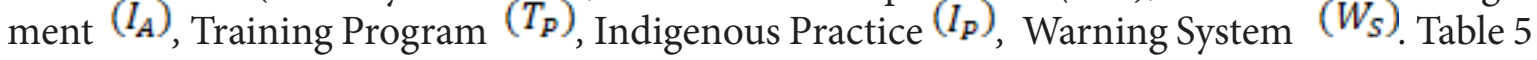
shows that the value of Flood Vulnerability Index (FVI) of every union for social dimension. According to the table, Saidabad union is more socially vulnerable among ten unions.

Economic Vulnerability: The income and prosperity of the study area are depicted in the economic dimension. These metrics would provide information about the capacity to generate and deliver flood-prone goods and services. Developing countries, for example, are characterized by low per capita income, a shortage of human resources, a lack of investment and finance, and weak infrastructure. Developed countries, on the other hand, are characterized by substantial investments in prevention and countermeasures, long life expectancy, flood insurance, and urban planning, among other things. If economic growth accelerates, the risk of flooding will likely increase as well (Balica \& Wright, 2010). As a determinant of vulnerability, the indicators for economic vulnerability to flood for Sirajganj Sadar Upazila have been chosen. Six components have been chosen for the flood vulnerability index, which cover three indices under the economical dimension of flood vulnerability and provide an overview of the situation. Three of the six elements are exposure, one is susceptibility. and the other two are flood resilience. The components of exposure are Household Assets $\left(H_{A}\right)$ Agricultural Dependency $\left(A_{D}\right)$, Income Source $\left(I_{S}\right)$; component of susceptibilitv is Unemployment Rate $\left(U_{M}\right)$ and components of resilience are Economic Diversification ${ }^{\left(E_{D}\right)}$, Flood Insurance $\left(F_{I}\right)$. Table shows that the value of Flood Vulnerability Index (FVI) of every union for economic dimension. According to the table, Bahuli union is more economically vulnerable than ten unions. 
Environmental Vulnerability: The environmental aspect involves indicators that relate to the environmental damage caused by floods or intrusion caused by human beings that could increase the vulnerability of certain areas. Activities such as farming, urban growth and forestry have been shown to generate greater vulnerability to flooding which can lead to more pollution (Balica \& Wright, 2010). As a factor determining the vulnerability, environmental indicators for Sirajganj Sadar Upazila have been chosen. Five components have been chosen to cover three social measures of the vulnerability of the flood and provide an overview of the situation for the flood vulnerability index. Two components include exposure. one is vulnerability and two are flood resistance. The components of exposure are Land use $\left(L_{U}\right)$, Monsoon Rainfall $\left(M_{R}\right)$; component of susceptibilitv is Riverbank Erosion $\left(R_{E}\right)$ and components of resilience are Embankment $(E)$, Water Body $\left(W_{B}\right)$. Table 5 shows that the value of Flood Vulnerability Index (FVI) of every union for environmental dimension. According to the table, Mechhra union is more environmentally vulnerable among ten unions.

Physical Vulnerability: The physical dimension contains how the physical conditions (natural or human-made) can influence the vulnerability of a particular region to floods. The indicators for physical vulnerability to flood for Sirajganj Sadar Upazila have been chosen as a determinant of vulnerability. For flood vulnerability index, six components have been chosen, which cover three indicators under social dimension of flood vulnerability and give an overview of the situation. Among six components, two components are exposure, one component is susceptibility and three are resilience to flood. The components of exposure

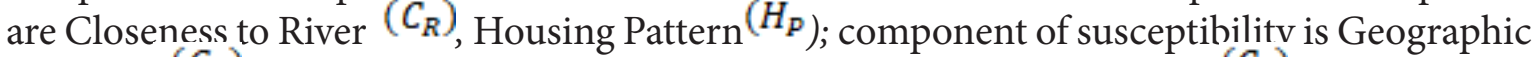
Location $\left(G_{L}\right)$ and components of resilience are Communication System ${ }^{\left(C_{S}\right)}$, Flood Shelter $\left(F_{S}\right)$. Table 5 shows that the value of Flood Vulnerability Index (FVI) of every union for physical dimension. According to the table, Mechhra union is the most physically vulnerable one to flood among ten unions.

The total Flood Vulnerability Index is calculated for each union using Formula (Eq. vi). Table 5 shows total Flood Vulnerability Index (FVI) for every unions where the highest index value is 1.00 at Mechhra union.

Table 5. Union wise Flood Vulnerability Index (FVI)

\begin{tabular}{|c|c|c|c|c|c|}
\hline $\begin{array}{c}\text { Dimension } \\
\text { Union }\end{array}$ & Social & Economic & Environmental & Physical & Total \\
\hline Baghbati & 0.07 & 0.16 & 0.30 & 0.08 & $\mathbf{0 . 6 1}$ \\
\hline Bahuli & 0.03 & 0.23 & 0.30 & 0.06 & $\mathbf{0 . 6 2}$ \\
\hline Kalia Haripur & 0.09 & 0.04 & 0.13 & 0.23 & $\mathbf{0 . 4 9}$ \\
\hline Kaoakola & 0.01 & 0.05 & 0.25 & 0.24 & $\mathbf{0 . 5 5}$ \\
\hline Khoksabari & 0.03 & 0.2 & 0.30 & 0.06 & $\mathbf{0 . 4 1}$ \\
\hline Mechhra & 0.01 & 0.14 & 0.60 & 0.25 & $\mathbf{1 . 0 0}$ \\
\hline Ratankandi & 0.02 & 0.08 & 0.45 & 0.08 & $\mathbf{0 . 6 3}$ \\
\hline Saidabad & 0.15 & 0.01 & 0.06 & 0.23 & $\mathbf{0 . 4 5}$ \\
\hline Shialkul & 0.07 & 0.06 & 0.30 & 0.11 & $\mathbf{0 . 5 4}$ \\
\hline Chhangachha & 0.03 & 0.04 & 0.30 & 0.15 & $\mathbf{0 . 5 2}$ \\
\hline
\end{tabular}

(Prepared by: Authors, 2019)

Table 6 shows union wise Flood Vulnerability Interpretation where six unions are high vulnerable to flood which index value range is $0.50-0.75$. The most noticeable aspect of the table 6, Mechhra union is very high vulnerable to flood. 
Table 6. Union wise Flood Vulnerability Interpretation

\begin{tabular}{|c|c|c|}
\hline Index value & Description & Unions \\
\hline$<0.01$ & Very small vulnerability to floods & ------- \\
\hline $0.01-0.25$ & Small vulnerability to floods & ------- \\
\hline \multirow{3}{*}{$0.25-0.50$} & \multirow{3}{*}{ Vulnerable to floods } & Khoksabari (0.41) \\
\hline & & Saidabad (0.45) \\
\hline & & Kalia Haripur (0.49) \\
\hline \multirow{6}{*}{$0.50-0.75$} & \multirow{6}{*}{ High vulnerability to floods } & Chhangachha (0.52) \\
\hline & & Shialkul (0.54) \\
\hline & & Kaoakola $(0.55)$ \\
\hline & & Baghbati (0.61) \\
\hline & & Bahuli (0.62) \\
\hline & & Ratankandi (0.63) \\
\hline $0.75-1.00$ & Very high vulnerability to floods & Mechra (1.00) \\
\hline
\end{tabular}

(Prepared by: Author, 2019)

The FVI for environmental and physical dimension of Mechhra union is extending or reaching upward more than other unions. Because of its geographical location, this union is more environmentally and physically vulnerable. It has been observed from field survey, Mechhra union is located at middle in the river and it is a "Char Area". This union is very high vulnerable for its low resilience and lack of indigenous coping capacity. Final result has been shown in Figure 2. From the map, it is clearly understood that, Mechhra union is in very high vulnerable zone; Baghbati, Bahili, Ratankandi, Shialkul, Kaoakola, Chhangachha unions are in high vulnerable zone; Khoksabari, Saidabad, Kalia Haripur unions are in vulnerable zone. 


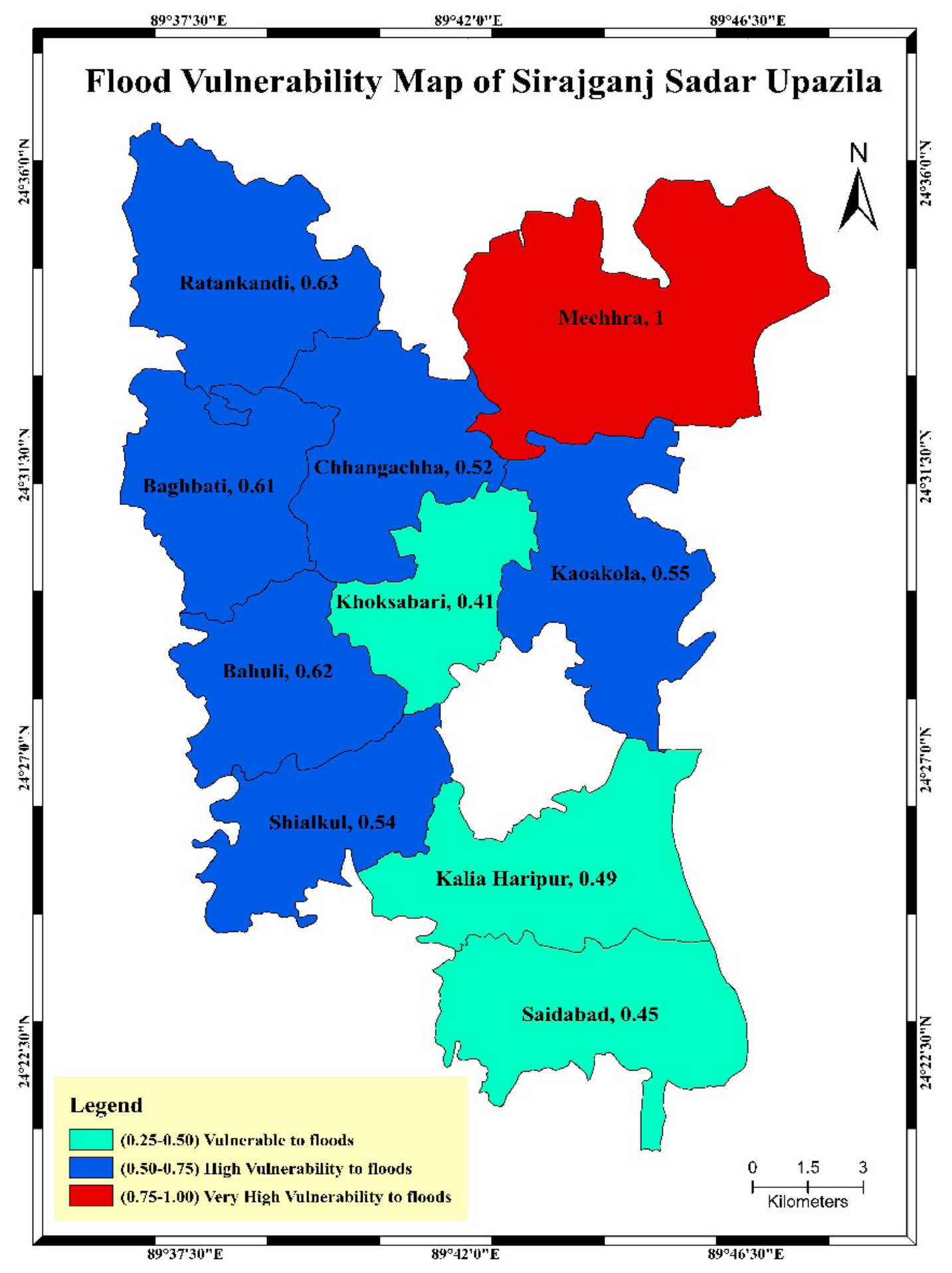

(Prepared by: Author, 2019)

Figure 2. Flood Vulnerability Map of Sirajganj Sadar Upazila

\section{Conclusion}

sirajganj district is one of Bangladesh's flood-prone regions. This study introduces a method of indexing, which is applied to determine flood vulnerability and focuses on Sirajganj Sadar Upazila flood susceptible unions. This research also offers a summary of the Flood Vulnerability Index (FVI) framework assessment methods for flood vulnerability. The whole 
FVI concept is that the area (Sirajganj Sadar Upazila) is affected by a four dimensional flood risk (social, economic, environmental and physical). This research covers a thorough review and understanding of flood vulnerability measures, i.e. exposure, sensitivity and resilience. The finding of the study is the comparative vulnerability analysis among the ten unions of the upazila. This result will be helpful to design any kind of flood risk management measures for Sirajganj Sadar Upazila.

\section{REFFERENCES}

1. Balica, S. F. (2012). Applying the flood vulnerability index as a knowledge base for flood risk assessment, Delft University.

2. Balica, S. F. and Wright, N. G. (2010). Reducing the complexity of the flood vulnerability index. Environmental Hazards, 9(4), 321-339. http://dx.doi.org/10.3763/ehaz.2010.0043

3. Banglapedia. (2014). Sirajganj Sadar Upazil. Retrieved 9 August, 2018 from http:// en.banglapedia.org/index.php?title=Sirajganj_Sadar_Upazila

4. Bhattacharya, B., Suman, A., Haque, A., Khan, M. F. A. and Maswood, M. (2013). "Flood Characteristics of the Haor Area in Bangladesh", Proceeding of $4^{\text {th }}$ International Conference on Water and Flood Management, vol.1, pp.167-175, Dhaka, Bangladesh, 2013.

5. Bhuiyan, M.S.R., Flood Hazard and Vulnerability Assessment in a Riverine Flood Prone Area: A Case Study, M.Sc. Thesis, IWFM, Bangladesh University of Engineering and Technology, 2014.

6. Dewan, T. H. (2015). Societal impacts and vulnerability to floods in Bangladesh and Nepal. Weather and Climate Extremes. http://dx.doi.org/10.1016/j.wace.2014.11.001i

7. Disaster Management in Bangladesh (2003). Retrieved 13 August, 2018 from http://www. adrc.asia/countryreport/BGD/2003/page2.html

8. Fakhruddin, S. H. M., Kawasaki, A. \& Babel, M. S. (2015).Community Responses to flood early warning system: Case study in Kaijuri union, Bangladesh, International Journal of Disaster Risk Reduction, http://dx.doi.org/10.1016/j.ijdrr.2015.08.004

9. Flax, Lisa K., Jackson, Russell W., and Stein, David N., "Community Vulnerability Assessment Tool Methodology," NaturalHazards Review, ASCE, 3(4), 163- 176, 2002.

10. Klein, R. J. T. and Nicholls, R. J. (1999). Assessment of coastal vulnerability to climate change, Ambio, 28(2), pp. 182-187, 1999.

11. Nasiri, H. (2013). Flood Vulnerability Index as a Knowledge Base for Flood Risk Assessment in Urban Area. Novel Applied Sciences, 2(8), 269-272.

12. Pouya, A. S., Nouri, J., Mansuri, N. and Lashak, A. K. (2017). An indexing approach to assess flood vulnerability in the western coastal cities of Mazandaran, Iran. International Journal of Disaster Risk Reduction. http://dx.doi.org/10.1016/j.ijdrr.2017.02.013

Funding: "This research received no external funding"

Conflicts of Interest: The authors declare no conflict of interest. 